\title{
Laparoscopy hepatic biopsy through cauterization
}

\author{
Biópsia hepática laparoscopica por cauterização
}

\begin{abstract}
Alexandra Pinheiro Fantinatti ${ }^{1}$ Carlos Roberto Daleck $^{2}$ Newton Nunes $^{3}$ Antonio Carlos Alessi ${ }^{4}$ João Moreira da Costa Neto ${ }^{6}$ Felipe Antonio Mendes Vicenti ${ }^{1}$ Juan Carlos Duque ${ }^{5}$

Paulo Sérgio Patto dos Santos ${ }^{1}$
\end{abstract}

\section{ABSTRACT}

Hepatic biopsy was realized through laparoscopy with simultaneous cauterization in the present study, whose principal aim was to evaluate the efficacy of the applied method and to study its effects in the liver of healthy dogs. Furthermore, we tried to verify the main hematological and chemistry profile alterations related to the hepatic function, and to investigate the viability of the fragments collected by histopathology. To attain this objective, 21 clinically healthy dogs, weighing between 10 and $15 \mathrm{~kg}$ were submitted to hepatic biopsy with forceps connected to the cautery. Cautery was performed by applying radiofrequency energy at 45 watts. Forty-two hepatic biopsies through laparoscopy were conducted in the animals. At group I one hepatic fragment per animal was collected, at group II two hepatic fragments per animal were collected, and at group III three fragments were collected. Hematocrit and alanine-aminotransferase measurements were employed to evaluate the animals at the pre-operative period, at four and six hour post-operative, and at day 30 post-operative. The results revealed that the procedure was safe and effective for hepatic biopsy in dogs. There were no clinical alterations related to the technique. The fragments collected were viable for histopathology. Hepatic biopsy through laparoscopy with simultaneous cauterization is an effective and usefull method in dogs.

Key words: electrocautery, dog, surgery, diagnosis.

\section{RESUMO}

Este estudo visou avaliar a eficácia do método de biópsia hepática laparoscópica por cauterização e estudar os seus efeitos no figado de cães sadios. Além disso, procurou-se verificar as principais alterações hematológicas e bioquímicasséricas relacionadas às funções hepáticas e averiguar a viabilidade dos fragmentos colhidos por exame de histopatologia. Para tanto, 21 cães clinicamente sadios pesando entre 10 e $15 \mathrm{~kg}$, foram separados em três grupos de sete animais cada grupo. As amostras foram retiradas da borda no lobo lateral esquerdo, utilizando-se pinça de biópsia conectada a eletrocautério na freqüencia de $45 \mathrm{~W}$. Foram realizadas 42 biópsias hepáticas por laparoscopia nos 21 animais suprareferidos. No grupo I, colheu-se um fragmento hepático por animal. No grupo II, colheram-se dois fragmentos e no grupo III, colheram-se três fragmentos por animal. Os cães foram

${ }^{1}$ Médico Veterinário, Doutorando em Cirurgia Veterinária, Faculdade de Ciências Agrárias e Veterinárias, Universidade Estadual Paulista (UNESP). Via de Acesso Prof. D. Castellane S/N, 14870-000, Jaboticabal-SP. E-mail apfantinatti@aol.com. Autor para correspondência.

${ }^{2}$ Médico Veterinário, Professor Adjunto, Departamento de Clínica e Cirurgia Veterinária/Faculdade de Ciências Agrárias e Veterinárias, Jaboticabal - UNESP.

${ }^{3}$ Médico Veterinário, Professor Assistente Doutor, Departamento de Clínica e Cirurgia Veterinária/Faculdade de Ciências Agrárias

e Veterinárias, Jaboticabal - UNESP.

${ }^{4}$ Médico Veterinário, Professor Titular, Departamento de Patologia Veterinária/Faculdade de Ciências Agrárias e Veterinárias, Jaboticabal - UNESP.

${ }^{5}$ Médico Veterinário, Mestrando em Cirurgia Veterinária, Faculdade de Ciências Agrárias e Veterinárias, Jaboticabal - UNESP.

${ }^{6}$ Médico Veterinário, Professor Doutor, Universidade Federal da Paraíba (UFPB), Patos-Pb. 
avaliados nos periodos pré, pós-operatório (tempos 4 h e 6h) e aos 30 dias de evolução. Os resutados obtidos revelaram que não houve alterações hematológicas, bioquímicas e histopatológicas relacionadas à técnica. Não foram observadas alterações significativas nos parâmetros estudados, sugerindo que não ocorreram alterações hepáticas que comprometessem a função do órgão.

Palavras-chave: eletrocauterização, cão, cirurgia, diagnóstico.

\section{INTRODUCTION}

The use of laparoscopy in the diagnosis of hepatic diseases was not frequent in past decades due to a lack of trust in the application of this technique, and to the increasing popularity of radiographic and ultrassonographic procedure. However, laparoscopy for hepatic biopsy is considered today the most precise method for diagnosing hepatic disease (NORD, 1992). Liver biopsy is indicated to estabilish definitely the presence and cause of the liver disease, to determine an apropriate development to therapy and, finally, to permit the clinican an estabilishment of prognosis (JOHNSON \& TWEDT, 1997; MAGNE \& WITHROW, 1985; JONES, 1990; NORD, 1992; GOMES, 1993; ROTH \& MEYER, 1995). The direct inspection of the liver, associated to the biopsy is indicated in cases that require fast solution or that cannot be obtained by noninvasive techniques (NORD, 1992). The use of laparoscopy in hepatic disease can contribute to a precise diagnosis, it is indicated in cases of hepatic cirrosis, cronic hepatitis, portal vein disorders, hepatic neoplasias and cists, among others (MASSOUD, 1996). Nevertheless, experience and ability of the professional who conducts the exam are fundamental. The velocity and precision of this technique are directly bound to the factors necessary to a good result of laparoscopy: the equipment, the procedure, the anesthesia, the anatomy and the conditions of the patient. However, many attemps of collecting bigger samples trough hepatic biopsy were followed by many complications, including hemorrhagic processes of difficult solution or, sometimes, even irrevocable. Considering that the apllication of this technique in our environment is still rudimental, the aim of this study is to evaluate the viability of hepatic biopsy through laparoscopy, by cauterization, considering the quality of the collected material, as well as to study, through subsequent laparotomy, the results related to possible hemorrhages or another local alterations deriving from the method being tested.

\section{MATERIAL AND METHOD}

Twenty-one clinically healthy mongrel adult dogs, eleven females and ten males, weighing between
10 and $15 \mathrm{~kg}$, were used in this study. Forty-two biopsies through laparoscopy were conducted in the 21 animals previously cited, distributed in three groups of seven animals each. In group I one hepatic fragment per animal was collected. In group II two hepatic fragments were collected. In group III three hepatic fragment were collected per animal. The fragments were collected in the left lateral lobe, side by side, with intervals of $0,5 \mathrm{~cm}$ between them. Levomepromazine in the dose of $1 \mathrm{mg} /$ $\mathrm{kg}$ was injected intravenously as a pre-anesthesic medication, followed by induction, 15 minutes later, with Tiletamine/Zolazepan, intravenously, in the dose of $5,0 \mathrm{mg} / \mathrm{kg}$. Then, the animals were submitted to the oro-traqueal intubation (in order to volatile anesthesic Halotane diluted in oxygen). The exploratory laparoscopy surgical technique with hepatic biopsy was conducted in the epigastric region, in the midline and under the inferior margin of the diafragmatic muscle (imaginary line of insertion of the diafragm, 1 to $2 \mathrm{~cm}$ to the xifoid cartilage). A $1 \mathrm{~cm}$ incision was made through the skin followed by blunt dissection through the muscle layers to the peritoneum, a optical surgical trocar and cannula were placed through the skin, the optical trocar was then removed and a laparoscope attached to the light source by a flexible fiber light cable was guided through the cannula and into the abdomen. The operating laparoscope was designed to allow internal organ biopsy or surgical manipulation without the insertion of a secondary accessory cannula.

Then, apprehension forceps with a concave and sharp borders, was connected to the electrocautery with the aim of collecting liver, and, simultaneously, to cauterize the injury produced. The electrocautery was ajusted to cut and clotting with the intensity of $45 \mathrm{~W}$ of the potency to hemostasia. The fragments were collected in the left lateral hepatic lobe, with dimensions proportional to the collection compartment of the applied forceps. The animals were evaluated during 24 hours after surgery. The interval until anesthesia recovery, interval to return of apetite, vomiting, diarrhea, prostration, and presence of abdominal discomfort were observed. The animals were submitted to pre and post-operative hematocrit and alanineaminotransferase evaluations (on time " 0 " imediatelly before surgery, 4 and 6 hours post-operative, and 30 post-operative day). On 30 post-operative day, a laparotomy was realized. The morfhological features of the sites of collection of the hepatic fragments and eventual lesions deriving from cautherization, as well as another possible complications, like infections or adherencies were observed. The material collected from the hepatic segment through laparoscopy was immersed in a $10 \%$ formaldehyde fixing fluid, tamponade 
with fosphates, $\mathrm{pH} 7,2$, remaining there for more than 24 hours for fixation. Then, the fragment was cut sagitally on its major extension and submitted to the routine thechnique for paraffin embedding of the Veterinary Pathology Departament of the São Paulo State University/UNESP-Jaboticabal.

$5 \mu \mathrm{m}$ sections were obtained from the hepatic fragments and stained by Hematoxylin and Eosin dye. Some samples, stained as well, were included in glicol metacrilate. The following parameters were accessed: preservation of material and presence of artefates, preservation of the frame of the organ for identification, amount of material and eventual lesions produced by the biopsy. The values of hematocrit and alanineaminotransferase were statistically analysed (Tukey's Test $5 \%$ ), with the aim of gauging the medium values and accessing the behavior of the parameters among the groups and into the groups on stablished times.

\section{RESULTS}

The animals presented good clinical condition. There were no hematocrit and alanineaminotransferase alterations. Sistemic or local alterations that could be related to surgical complications were not observed. During the operatory period, visualization of the epigastric region of the abdomen permitted the study of some anatomical elements (liver, gall bladder, spleen, stomach). Alterations on shape, colour and localization of liver were not verified. The differences in visualization found in two animals were due to the lateral displacement of the splen. Three animals presented bleeding in three biopsy sites after collection and cauterization of the hepatic fragment, becoming necessary to repeat the procedure of cauterization. This repetition was enough to eliminate the hemorrhage. During the first 24 hours after the surgical proceeding only two animals presented a late anesthesic recovery ( $>1$ hour), as well as vomiting and apathy in the first four hours. The macroscopic exam of the liver, realized after day 30 postoperative, revelead regeneration at the biopsy sites in only six animals of group I $(28,6 \%)$.

The other animals presented scar connective tissue $(42,8 \%)$; adherencies in the biopsy sites in six animals $(28,6 \%)$ were observed, one of them involving the falciforme ligamentum, and the others involving the epiplon. The sections of the fragments collected were directly measured in the slide with a milimitered ruler in their two dimensions, verifying that $73,8 \%$ measured $3 \times 5 \mathrm{~mm}, 4 \times 5 \mathrm{~mm}, 3 \times 4 \mathrm{~mm}$ ou $4 \times 4 \mathrm{~mm}$. The smallest section measured $2 \times 3 \mathrm{~mm}$ and the largest $4 \times 6 \mathrm{~mm}$. These dimensions showed to be enough for histopathology analysis, verifying that there was always the presence of intact hepatic lobes that permitted to localize the lesions inside these structyres of them organ. The majority of the sections were intact, however six sections $(14,6 \%)$ presented a fragmentation or mechanic compression, distorting partially its structure. In those cases, however, there was not damage able to impair the analysis. The histopathologic findings observed with the vacuolization were represented specially by hidropic degeneration. Sometimes the vacuolization was present in determined areas of the hepatic lobe, for example, in the center of the lobe or peri-portal, except the artefate. Other observation were: mononuclear inflamatory cells infiltrate in the portal space, portal fibrosis and an increase in the number of resident fagocitic cells (Kupfer Cells).

\section{DISCUSSION}

The many modalities of diagnostic techniques employed in controlling abdominal injuries present advantages and disadvantages, that vary according to the patient, clinical situation and type of injury. The choice of most indicated technique should be based in its viability, riscs and costs, with the rising of laparoscopy many surgeons have been getting familiar with this technique. According to GOMEL (1976), in patients with atypical abdominal injuries, the diagnosis can be certainly reached by laparoscopy. Nevertheless, according to EASTER et al. (1992), the use of this technique in medicine, is still not frequent. The species chosen for this study was adequate to the development of the technique in this type of experiment. The same species was used by JOHNSON \& TWEDT (1977), GOMES (1993) and SALVINO et al. (1993). The access to the laparoscopy technique was placed in the epigastric region, in the medline, as described by GOMES (1993), which permitted the visualization of the many anatomical elements os the studied region. The differences in visualization found in two animals were due to the lateral displacement of the spleen. This did not avoid the realization of the exam. Such limitations were also described by LIVINGSTON et al. (1992) and IVATURY et al. (1993). According to BERCI et al. (1991), the visualization of some areas can be realized through placement of a second trocart. GOMEL (1976); NAGY \& JAMES (1989) and GOMES (1993) described the laparoscopy technique as a secure and succesfull method in the visualization of the intracavitary structures. The electrocauterization associated to the biopsy in this study resulted in a effective hemostasia. This result agrees with those obtained by 
KRAUSZ et al. (1984); OLIVENCIA (1985) and FINAN et al. (1996) when they tested the technique in medicine or in research with dogs (KLUGE \& ULLAL, 1971; KIM et al., 1993). The radiofrequency energy at $45 \mathrm{~W}$ was secure and didnct produce alterations in the samples, as comfirmed by histopathology. This fact agrees with the results obtained by FINAN et al. (1996) although in this case, the frequency used was $40 \mathrm{~W}$. Otherwise if higher frequency are employed, the sample can be alterated, as described by KIM et al. (1993) who employed the frequency of $125 \mathrm{~W}$, and observed a $10 \%$ compromise in the collected fragments.

The hemorrhage obseved during the three collections didn $\phi t$ mean an increase in the risc factor of the technique, because a second electrocauterization a few seconds after the collection of the sample was enough to stop the bleeding. An equivalent procedure was already adopted by OLIVENCIA (1985) with similar results. The combination "cut" and "clotting" was considered and employed based on the studies of KLUGE \& ULLAL (1971) who could complete the hemostasia obtaining a dry and sterile surface with minimal tissue necrosis. The microscopic exam proposed in our study verified, through histhological of the collected fragments the viability of the technique employed, like KLUGE \& ULLAL (1971) and KIM et al. (1993). Data obtained by KIM et al. (1993) demonstrated the importance of the investigation through complementary exams, of the effects of the electrocauterization to hemostasia in liver which were related to portal hipertension and coagulopaties. Additionally, as suggested by FINAN et al. (1996), the possible hepatic lesions in the biopsy places should be evaluated by exploratory laparotomy. As related by KIM et al. (1993) and FINAN et al. (1996), in this study could be established the effects of electrocauterization after hepatic biopsy through exploratory laparotomy after 30 days of surgery and by the results of statistical analysis in the evaluation of the hematocrit and of the seric activity of the alanine-aminotransferase.

\section{CONCLUSIONS}

The use of electrocauterization in a frequency energy at 45 watts, combining cutand clotting, and a monopolar equipment assure the hemorrhage control, that was obtained in a few moments, stablishing a dry hepatic surface, with a minimum of tissue necrosis. The technique is considered safe and effective for hepatic biopsy in dogs. No clinical changes associated with the procedure were detected. The hepatic biopsy using laparoscopy and simultaneous cauterization constitutes an important diagnostic method in dogs.

\section{SOURCES AND MANUFACTURES}

a - Levomepromazine. Rhodia S.A.

b - Tiletamine/Zolazepan. Fort Dodge Saúde Animal Ltda. - Brasil.

c-Halotane. Cristália do Brasil. São Paulo, SP.

\section{ACKNOWLEDGEMENTS}

The author wish to thank CAPES (Coordenação de Aperfeiçoamento Pessoal de Nível Superior).

\section{REFERENCES}

BERCI, G.; SACKIER, J. M.; PAZ-PARTLOW, M. Emergency laparoscopy. The American Journal of Surgery, v.161, p.332-335, 1991.

EASTER, D.W. et al. The utility of diagnostic laparoscopy for abdominal disorders. Archives of Surgery, v.127, p.379383, 1992.

FINAN, M.A. et al. Intraoperative liver biopsy with the loop electrosurgical excision procedure in patients with gynecologic malignancies. Gynecologic Oncology, v.62, p.78-81, 1996.

GOMEL, V. Laparoscopy in general surgery. The American Journal of Surgery, v.131, p.319-323, 1976.

GOMES, H.M. Contribuição para o estudo da laparoscopia diagnóstica no cão: técnicas de abordagens e anatomia topográfica laparoscópia. 1993. 86f. Dissertação (Mestrado em Veterinária) - Faculdade de Medicina Veterinária, Universidade de São Paulo.

IVATURY, R.R.; SIMON, R.J.; STAHL, W.M. A critical evaluation of laparoscopy in penetrating abdominal trauma. The Journal of Trauma, v.34, p.822-828, 1993.

JOHNSON, G.F.; TWEDT, D.C. Endoscopy and laparoscopy in diagnosis and managment of neoplasia in small animals. Veterinary Clinics of North America: Small Animal Practice, v.7, p.77-99, 1977.

JONES, B.D. Laparoscopy. Veterinary Clinics of North America: Small Animal Practice, v.20, p.1243-1263, 1990.

KIM, E.H. et al. Eletrocautery of the tract after needle biopsy of the liver to reduce blood loss. Experience in the canine model. Investigative Radiology, v.28, p.228-230, 1993.

KLUGE, T.H.; ULLAL, S.R. Electrosurgery in resections of the liver. American Journal of Surgery, v.122, p.792-796, 1971

KRAUSZ, M.M.; FREUND, H.R.; DURST, A.L. A simplified method for intraoperative biopsy of the liver. Journal Article, v. 158, p. $177,1984$.

Ciência Rural, v. 33, n. 4, jul-ago, 2003. 
LIVINGSTON, D.H. et al. The role of laparoscopy in abdominal trauma. Journal of Trauma, v.33, p.471-475, 1992.

MAGNE, M.L.; WITHROW, S.J. Hepatic neoplasia. Veterinary Clinics of North America: Small Animal Practice, v.15, p.243-256, 1985.

MASSOUD, W.Z. Laparoscopic excision of a single hepatic hydatid cyst. International Surgery, v.81, p.9-13, 1996.

NAGY, A.G.; JAMES, D. Diagnostic laparoscopy. American Journal of Surgery, v.157, p.490-4933, 1989.
NORD, H.J. Complications of laparoscopy. Endoscopy, v.24, p.693-700, 1992.

OLIVENCIA, J.A. A simplified method of wedge liver biopsy. Journal Article, v.158, p.355-356, 1985.

ROTH, L.; MEYER, D.J. Interpretation of liver biopsies. Veterinary Clinics of North America: Small Animal Practice, v.25, p.293-303, 1995.

SALVINO, C.K. et al. Laparoscopic injection of fibrine glue to arrest intraparenchymal abdominal hemorrhage: an experimental study. Journal of Trauma, v.35, p.762-766, 1993. 